\title{
Are Family Firms Different in Choosing and Adjusting Their Capital Structure? An Empirical Analysis through the Lens of Agency Theory
}

\author{
Ottorino Morresi ${ }^{1} \&$ Alessia Naccarato ${ }^{1}$ \\ ${ }^{1}$ Department of Economics, University of Roma Tre, Via Silvio D’Amico 77, Rome, Italy \\ Correspondence: Ottorino Morresi, Department of Economics, University of Roma Tre, Via Silvio D'Amico 77, \\ 00145, Rome, Italy. Tel: 39-06-5733-5753. E-mail: ottorino.morresi@ uniroma3.it
}

Received: April 20, 2016

Accepted: June 7, 2016

Online Published: June 25, 2016

doi:10.5539/ijef.v8n7p216

URL: http://dx.doi.org/10.5539/ijef.v8n7p216

\begin{abstract}
How do family firms choose and adjust their capital structure? A significant number of contributions have examined the problem from several angles but many issues remain a puzzle. We examine capital structure choices of family firms in Italy, a context characterized by high private benefits of control, separation between ownership and control, and diffusion of family-controlled pyramidal groups. Consistent with the agency-based models, family firms are found to be more leveraged than non-family counterparts as a result of their desire to hold control. We also find higher debt ratios in firms with a higher separation between ownership and control if and only if the firm is controlled by a family. This lends support to the fact that controlling families may want to allocate more debt to subsidiaries, where the separation is higher, in order to inflate assets under domination at the expense of minority shareholders, while controlling negative effects in case of bankruptcy of an affiliate. Finally, family firms are also found to behave differently when they adjust their debt ratio. We show that leverage persistence is higher in family firms because they bear higher adjustment costs as a result of higher agency costs of equity, but lower costs of deviating from the optimal debt level, because the tight links between controlling families and banks may allow family owners to negotiate deviations with banks more easily.
\end{abstract}

Keywords: expropriation, family ownership, leverage, pyramidal group, speed of adjustment

\section{Introduction}

Capital structure choice of family firms continues to be an open research question and a fruitful area of enquiry. What do we know about the choice between equity and debt financing of family firms? Two main perspectives can be outlined: on the one hand, family firms may be expected to be less leveraged than non-family firms as a result of the risk aversion of family members that have a large fraction of their financial and human capital tied to the firm. Likewise, family members may be well disposed to maintain low debt levels in order to reduce bankruptcy risks that may jeopardize the purpose to bequeath the firm to heirs (Mishra \& McConaughy, 1999). Their supposed long-term orientation (Casson, 1999; Chami, 2001) may therefore explain a lower leverage ratio in family firms than in non-family counterparts. On the other hand, family firms may want to avoid issuing equity so as to minimize the risk of diluting the family's controlling stake. According to the behavioral theory, the desire to hold control would stem from the independence preference of the entrepreneur, especially in small businesses, who does not like the interference of outside shareholders (Hutchinson, 1995; Romano et al., 2001). According to the agency theory, controlling families want to retain control in order to keep gaining private benefits of control, especially when internal and external governance mechanisms are weak (Faccio et al., 2001; Burkart et al., 2003; Anderson \& Reeb, 2004; Anderson et al., 2009).

From this perspective, Shleifer and Vishny (1997), La Porta et al. (1999) and Bebchuk et al. (2000) take into account the agency relationship between majority and minority shareholders (hereafter, Type II agency relationship). Controlling families, by making large use of control-enhancing mechanisms such as pyramidal groups, dual-class shares, etc., may separate ownership from control, therefore having the inclination to expropriate wealth from minority shareholders because they only bear a fraction of the total cost of consuming a firm's resources. Recent studies (Filatotchev \& Mickiewicz, 2006; Bianco \& Nicodano, 2006; Faccio et al., 2007, 2010; Driffield et al., 2007; King \& Santor, 2008; Paligorova \& Xu, 2012) argue that debt, rather than a tool to constrain manager discretion, is a device used by the largest shareholder to expand resources under control and expropriate minority shareholders and creditors in firms with control rights that deviate from cash flow rights. 
However, all these studies seem to ignore the fact that most of the firms that rely on control-enhancing mechanisms are controlled by a family (Morck et al., 2005; Villalonga \& Amit, 2009; Bennedsen et al., 2010) and that the higher use of debt in firms with a higher level of separation between voting and cash flow rights may be linked to the family character of the largest shareholder.

The first key contribution of the paper is therefore to examine the debt level as well as the adaptation of debt levels in family firms compared to non-family counterparts, trying to disentangle the effect of family ownership from that of the separation between ownership and control, while revealing potential interactions between the two factors. Based on the agency theory, we analyze capital structure decisions of family firms from the perspective of expropriation risks on a sample of 107 Italian non-financial listed firms over the period 2000-2006 Italy is a suitable environment characterized by high ownership concentration, separation between ownership and control, large incidence of family-controlled pyramidal groups, and high private benefits of control (Aganin \& Volpin, 2003; Nenova, 2003; Dyck \& Zingales, 2004; Bianchi \& Bianco, 2006; Caprio \& Croci, 2008; Mengoli et al., 2009).

The second key contribution of the paper is that if Type II agency relationship is poor because of the presence of family ownership, especially when there is a high separation between ownership and control, family firms will face a higher cost of equity. This makes access to public and private equity markets more costly. From a dynamic perspective, and assuming the presence of a target leverage, this implies that family firms' debt ratios will converge on the target at a slower pace than they do in non-family counterparts as a result of higher adjustment costs. This argument may also be observed from the perspective of agency costs of debt (Anderson et al., 2003; Ellul et al., 2007; Steijvers \& Voordeckers, 2009). Tight and trust-based relationships between family owners and banks reduce agency costs of debt that, in turn, allow family firms to maintain a leverage ratio far from the target without banks requiring them to reduce its level. Good agency relationships between controlling families and banks make deviations from target leverage more negotiable, with little or no penalty. We argue that Italian family firms face lower agency costs of debt because of the tight links between controlling families and banks (Bianchi et al., 2001; Santella et al., 2007).

We find that family firms are more indebted than non-family counterparts and, more importantly, higher separation between ownership and control does not lead to higher debt ratios unless the firm is controlled by a family. This means that in a context with concentrated ownership structures, separation between ownership and control, and large incidence of family-controlled firms, debt is an instrument used to expand resources under family control and expropriate minority shareholders. We also find that family firms tend to have a far higher leverage persistence as a result of higher adjustment costs and lower costs of deviating from the target leverage.

The remainder of the article is organized as follows: Section 2 provides a review of literature on the use of debt in family firms largely based on the agency theory. In this section we also model our hypotheses; Section 3 describes the econometric approach; Section 4 provides data description; Section 5 shows the main results; Section 6 discusses and concludes.

\section{Debt Financing in Family Firms: The Agency Theory Approach and the Italian Case}

Shleifer and Vishny (1997), La Porta et al. (1999), and Bebchuk et al. (2000) argue that family firms may face severe Type II agency costs. The interest of minority and majority shareholders may collide to the extent that the amount of wealth invested in the firm by the controlling shareholder, therefore its risk exposure, may be disproportionately lower than its voting power. This condition may result from the use of pyramidal groups, dual-class shares and other instruments designed to separate cash flow rights from voting rights. Why is this problem supposed to be particularly serious in family firms? Several studies document that most family firms are controlled by making large use of control-enhancing mechanisms (Morck et al., 2005; Villalonga \& Amit, 2009; Bennedsen et al., 2010). This creates separation between cash flow rights and voting rights and induces the controlling shareholder to extract private benefits that, as such, do not accrue to minority shareholders, while insulating itself from excessive risk exposure and wealth losses should bankruptcy occur. The incentive to expropriate wealth from minority shareholders also resides in the concentrated portfolio exposures that characterize family owners. Rationality implies that such exposures result from the existence of counterbalancing benefits. Private benefits of control may be one such benefit. In consequence, family firms tend to be more prevalent in settings with large private benefits (Bennedsen et al., 2010). Type II agency relationship may also affect agency costs of debt to the extent that non-diverted assets may or may not be sufficient to pay interests and principal amount.

Family firms will therefore be reluctant to issue equity so as to avoid any control dilution problem as well as any interference from outside, minority shareholders. Poutziouris et al. (1998) find that a high proportion (50\%) of 
owners of privately-held firms generally avoid sources of finance that weaken links between ownership and control. Romano et al. (2001) find that family businesses, whose owners have a strong preference for retaining family control, are more likely to derive their funds from bank debt and leasing arrangements. Wiwattanakantang (1999), Harijono et al. (2004), and King and Santor (2008) find that family firms are more leveraged than non-family counterparts because controlling families do not want to risk losing control in order to continue to obtain private benefits of control.

The Italian context is characterized by a large diffusion of family-controlled groups structured as pyramids with several layers, sometimes issuing non-voting shares. Bianchi and Bianco (2006) show that, in Italy, the percentage of listed and non-listed firms with more than 50 employees controlled by a pyramidal scheme was $56.5 \%$ in $1993,44.0 \%$ in 2003 , and $45.8 \%$ in 2005 . They also show that the average "leverage", that is, voting rights per unit of capital owned by the largest shareholder, was 4.28 in 1992, 2.22 in 1998, and 2.33 in 2001.

The common use of control-enhancing devices, especially pyramidal groups, is accompanied with a relatively high value of private benefits of control. Nenova (2003) finds that, in Italy, the mean value of control-block votes as a share of firm value was about 30\% in 1997; only Mexico showed a higher value (about 36\%). Dyck and Zingales (2004) show that the average block premium as percentage of firm value was about $37 \%$ for a sample of control-block transactions occurred in Italy during the period 1990-2000; only Brazil, the Czech Republic, and Austria showed higher values. Caprio and Croci (2008) measure the voting premium in Italy from 1974 to 2003 and find that it has decreased over time but remained relatively high: it was 57\% in 1990, $65 \%$ in $1995,37 \%$ in 2000, and $20 \%$ in 2003.

Finally, we may indirectly infer that, in Italy, agency costs of debt may be lower in family-controlled firms than in non-family peers. Bianchi et al. (2001) and Santella et al. (2007), by analyzing the relevance of interlocking directorship in Italian listed firms, show a huge network of director interlocks. This network heavily involves directors of non-financial firms controlled by families that hold seats on the board of directors of banks and other financial institutions, and vice versa. This allows us to argue that family owners tend to be close to their financiers who may therefore monitor family agents better and build enduring and trust-based relationships with them. Lenders should therefore be less concerned of being expropriated by the controlling families, therefore applying improved credit conditions to family-controlled firms.

The picture described above clearly shows how the use of control-enhancing devices, the high private benefits of control as well as the hypothesized lower agency costs of debt should induce family firms to use higher debt ratios in order to allow the controlling family to hold control.

Hypothesis 1: Italian family-controlled firms are expected to be more leveraged than non-family counterparts.

The presence of separation between voting and cash flow rights and related expropriation risks are supposed and found to be linked to debt levels (Bianco \& Nicodano, 2006; Faccio et al., 2007, 2010; Driffield et al., 2007; King \& Santor, 2008; Paligorova \& Xu, 2012). The key argument is that when separation rises, debt may change its role. Instead of being a monitoring device, it may turn to be an instrument used by the controlling shareholder to expropriate wealth from minority shareholders and, ultimately, creditors (Faccio et al., 2007). More specifically, within a pyramidal group, the holding company enjoys the limited liability vis-à-vis the debt obligations of subsidiaries. Consequently, raising external debt from the operating unit gives the controlling shareholder the option of avoiding group bankruptcy by letting the single operating unit go bankrupt, when it is insolvent (Bianco \& Nicodano, 2006). This, in turn, implies that subsidiaries, where the ultimate largest shareholder typically holds a very small portion of cash flow rights, may raise a large fraction of group debt since limited liability insures the holding company from costly bankruptcy in adverse contingencies. This mechanism allows the largest shareholder to inflate assets under domination by allocating most of a firm's (risky) projects in the affiliates.

The empirical evidence is largely consistent with this prediction. Faccio et al. (2007) find a positive relationship between separation and leverage in a sample of Asian firms, but not in European firms. They argue that minority shareholders of European firms benefit from more effective capital market institutions that monitor the actions of the controlling shareholder better. This leads to a lower use of debt as expropriation mechanism in European firms. Conversely, Asian firms, that are supposed to have weak capital market institutions, experience a positive relationship between separation and leverage. Paligorova and Xu (2012) show that in developed countries, pyramid-affiliated firms, more exposed to expropriation problems, exploit debt to a greater extent. The inclination to use more debt persists but is significantly lower in countries with better creditor protection. According to Paligorova and Xu (2012), Faccio et al. (2010) show that leverage is significantly higher in corporations with a higher separation between voting and cash flow rights and in those headquartered where 
creditor protection is weaker. Driffield et al. (2007) and King and Santor (2008) seem to find results consistent to the above studies.

Assuming that family owners may be more disposed to use control-enhancing devices to acquire private benefits and expropriate minority shareholders, they are more likely to exploit debt financing to a greater extent in firms characterized by a larger deviation between cash flow rights and voting rights in order to expand resources under control to the detriment of minority shareholders, without bearing significant consequences in case of bankruptcy.

Hypothesis 2: The family character of the dominant owner positively moderates the relationship between separation and leverage ratio.

Family ownership may affect not only the debt ratios in a static context, but also the adaptation of debt levels in a dynamic perspective. The starting point consists in assuming the existence of a target leverage, that is, a hypothesized optimal level, dependent on firm-specific, industry-specific, and market-wide characteristics, which may vary over time, toward which a firm's leverage ratio may converge, in order to optimize the capital structure from the perspective of maximizing firm value (Flannery \& Rangan, 2006). We argue that family ownership may affect the speed at which a firm rebalances its leverage ratio towards the target as a result of its influence on agency costs. First, higher Type II agency costs in family firms make access to equity financing more difficult and costly. Family firms will therefore be less induced to issue equity. Second, issuing equity may threaten family control; family owners should therefore prefer debt in place of equity. Third, in Italy, families that control non-financial listed firms seem to have close ties to the banking system mainly through interlocking directorship (Bianchi et al., 2001; Santella et al., 2007) and personal connections. The tight links between family owners and banks give the lender superior monitoring abilities as well as the possibility to establish with the firm long-lasting and trust-based relationships that reduce agency costs of debt. From the demand side, we expect this characteristic to lower the cost of debt for family firms which will therefore find it relatively more convenient. From the supply side, this significantly reduces expropriation risks at the expense of creditors that, in turn, will be more disposed to offer credit to family firms on better conditions and negotiate suboptimal capital structures with controlling families without forcing the firm to bear punishment. The above discussion has two key implications. First, the adjustment costs should be higher in family firms. In fact, poor Type II agency relationships make access to public capital markets more difficult and costly, therefore reducing the range of opportunities to adjust the capital structure towards the target. Second, the costs of deviating from the target leverage should be lower in family firms. In fact, strict relationships between banks and controlling families make deviations from the optimal leverage ratio more negotiable.

Hypothesis 3: Family firms are supposed to have a lower speed of adjustment towards the target leverage than that of non-family counterparts.

\section{Econometric Specification}

The general formulation of the model to test capital structure determinants can be written as follows:

$$
y_{i, t}^{*}=a+\mathbf{b} \mathbf{X}_{\mathbf{i}, \mathbf{t}}+\varepsilon_{i, t}
$$

Where $i$ refers to firm, $t$ is the time, $y_{i, t}^{*}$ is the value of our leverage measures for the $i-t h$ firm at time $t$,

$a$ is the constant of the model, $\mathbf{X}_{\mathbf{i}, \mathrm{t}}$ is $(k \times 1)$ vector of the independent variables for the $i-t h$ firm at time

$t, \mathrm{~b}$ is the $(1 \times k)$ vector of the unknown parameters, and $\varepsilon_{i, t}$ is the innovation. Equation (1) is estimated by a

fixed effects model.

In order to assess the speed of adjustment, we consider the partial adjustment model which explains the change of firm leverage between two successive periods as a linear function of the difference between the target leverage and the leverage observed in a previous period. The adjustment equation is:

$$
y_{i, t}-y_{i, t-1}=(1-\lambda)\left(y_{i, t}^{*}-y_{i, t-1}\right)
$$


Where $\lambda$ is the unknown parameter which indicates the speed of adjustment, $y_{i, t}^{*}$ is the target leverage estimated by Equation (1), $y_{i, t}$ and $y_{i, t-1}$ are the values of our leverage measures, respectively, at time $t$ and $t-1$.

The more the $\lambda$ value is close to 0 , the less the firm takes time to converge on the target; the more the $\lambda$ value is close to 1 , the more the firm takes time to converge on the target.

The speed of adjustment is estimated through a one-step procedure. Without explicitly estimating the target leverage by Equation (1), we rearrange Equation (2) for $y_{i, t}$ and insert Equation (1) for $y_{i, t}^{*}$, then we obtain:

$$
y_{i, t}=a(1-\lambda)+\mathbf{b}(1-\lambda) \mathbf{X}_{\mathbf{i}, \mathbf{t}}+\lambda y_{i, t-1}+(1-\lambda) \varepsilon_{i, t}
$$

$\lambda$ is estimated by using two alternative specifications. The first one relies on the so-called GMM-SYS estimator proposed by Blundell and Bond (1998). This estimator is based on first differencing transformation to eliminate an unobserved firm-specific effect. It uses lagged values of endogenous or predetermined variables as instruments for first differences. GMM-SYS estimator is preferred among first-differenced instrumental estimators and GMM estimators for short sample periods and persistent data series such as ours. Lemmon et al. (2008) demonstrate that corporate leverage is highly persistent over time.

GMM-SYS estimator takes the first difference of Equation (3) as follows:

$$
y_{i, t}-y_{i, t-1}=\mathrm{b}(1-\lambda)\left(\mathrm{X}_{\mathrm{i}, \mathrm{t}}-\mathrm{X}_{\mathrm{i}, \mathrm{t}-1}\right)+\lambda\left(y_{i, t-1}-y_{i, t-2}\right)+(1-\lambda)\left(\varepsilon_{i, t}-\varepsilon_{i, t-1}\right)
$$

Equations (3) and (4) are then simultaneously estimated. GMM-SYS estimator uses lagged differences as instruments for Equation (3) and lagged levels as instruments for Equation (4).

The second approach relies on the long difference (LD) instrumental variables estimator proposed by Hahn et al. (2007) and, to the best of our knowledge, applied in a context of dynamic capital structure only by Huang and Ritter (2009), Drobetz and Schilling (2012), and Flannery and Hankins (2013). Hahn et al. (2007) demonstrate that GMM estimators have substantial bias for a large positive $\lambda$, which commonly occurs in the estimation of the speed of adjustment. Their approach is an instrumental variable estimator that uses a reduced set of instruments, in particular "long differences". This estimator also leads to a significant reduction in bias resulting from the problem of weak instruments.

The LD estimator is based on the following equation:

$$
y_{i, t}-y_{i, t-k}=\mathbf{b}(1-\lambda)\left(\mathbf{X}_{\mathbf{i}, \mathbf{t}}-\mathbf{X}_{\mathbf{i},-\mathbf{k}}\right)+\lambda\left(y_{i, t-1}-y_{i, t-k-1}\right)+(1-\lambda)\left(\varepsilon_{i, t}-\varepsilon_{i, t-k}\right)
$$

Where $k$ is the number of periods that define the differencing length.

Observation $y_{i, t-k-1}$ would serve as a valid instrument to estimate Equation (5) by means of two-stage least squares (2SLS). After having found the initial values of $\lambda$ and $\mathbf{b}(1-\lambda)$, we can further increase the explanatory power of the instruments by observing that the residuals $y_{i, t-1}-\lambda y_{i, t-2}-\mathbf{b}(1-\lambda) \mathbf{X}_{\mathbf{i}, t-1}$, $y_{i, t-k+1}-\lambda y_{i, t-k}-\mathbf{b}(1-\lambda) \mathbf{X}_{\mathbf{i}, \mathbf{t}-\mathbf{k}+\mathbf{1}}$ are also valid instruments. Then we use $y_{i, t-k-1}$ and the residuals as instruments to estimate Equation (5) through 2SLS. This procedure is then further iterated. According to Hahn et al. (2007), three iterations are usually sufficient to obtain reliable estimations.

\section{Data Description}

Our initial sample consists of 203 Italian non-financial listed firms that represent all Italian non-financial firms 
listed in 2000 on the Milan Stock Exchange. For the initial sample, we have checked data availability about accounting- and market-based data as well as information concerning a firm's ownership and control structure. Market-based information is collected from Datastream-Thomson Reuters database. Accounting-based information as well as information concerning a firm's ownership and control structure is collected from the following sources:

- Calepino dell'Azionista, a yearly publication edited by the research department of Mediobanca, the largest Italian investment bank, which provides information about the ownership structure of Italian listed firms, their accounting data, and biographical sketch, including address, foundation date, business description, etc..

- $\quad$ CONSOB web site, the web site of the public authority responsible for regulating the Italian securities market, which provides information about the "relevant" shareholders, that is, shareholders owning an equity stake equal to or greater than $2 \%$ in a listed firm.

- R\&S-Mediobanca, a yearly publication edited by the research department of Mediobanca, which provides information about consolidated and non-consolidated financial statements, and the ownership structure of the main Italian listed and privately-held corporate groups. Missing information about non-consolidated financial statements is collected from Settori-Online, a yearly publication edited by the research department of Mediobanca, which also provides information about non-consolidated financial statements of the main Italian listed and privately-held firms.

- Reports of chambers of commerce, which provide information about a firm's ownership structure. This source is used in order to fill missing data from the previous databases.

- Lexis-Nexis, which allows us to read annals of the most important Italian and international newspapers (e.g., Il Sole 24 Ore, La Stampa, The Wall Street Journal, Financial Times, etc.).

From the initial sample, we have left out firms with missing and incomplete data during the period starting in 2000 and ending in 2006, in order to obtain a balanced panel required to obtain more reliable estimations when using panel data models. The final sample consists of 107 Italian non-financial listed firms analyzed from 2000 to 2006 (749 firm-year observations).

Variable $y$ (market_leverage) (Note 1) is our leverage measure defined as:

interest - bearing debt

interest - bearing debt + equity

Interest-bearing debt is the book value of interest-bearing debt and equity is a firm's market capitalization. Vector $X_{i, t}$ includes observations of the $i-t h$ firm at time $t$ of the following variables.

\subsection{Independent Variables}

Votes-to-capital ratio is the ratio between voting rights and cash flow rights of the ultimate controlling shareholder. The ratio is the common measure of the separation between ownership and control. Voting rights are the result of the application of the weakest-link rule (Faccio \& Lang, 2002): in a control chain, the voting power held by the ultimate controlling owner is given by the voting stake held in the weakest link of the chain as this link is the most exposed to takeovers. Cash flow rights correspond to cash flow rights held by the ultimate largest shareholder. They are calculated by relying on the input-output model (Leontief, 1986) applied to shareholdings (Note 2).

Family is a dummy variable taking value 1 if the firm is family-controlled, 0 otherwise. A firm is family-controlled if the ultimate largest shareholder is a group of people linked by kinship that hold at least a 30\% voting stake as a whole. According to the Italian law on mandatory tender offers, a controlling shareholder is defined as an individual that holds at least a $30 \%$ voting stake. The identity of the ultimate largest shareholder is outlined by using R\&S-Mediobanca database and the reports of chambers of commerce that also show the ownership structure of non-listed firms (in pyramidal groups, holding and sub-holding firms are often non-listed companies). The family is identified by surname (stakes held by relatives with the same surname are considered as a whole). For families with more than one branch and family members with different surnames (e.g., founder's wife, sons of female heirs, etc.), family affiliation is also controlled by using Google search engine and Lexis-Nexis database to read annals of the most important Italian and international newspapers (e.g., Il Sole 24 Ore, La Stampa, The Wall Street Journal, Financial Times, etc.) (Note 3).

\subsection{Control Variables}

Firm_age is the natural logarithm of the number of years since firm foundation. Firm age could be used as a proxy for the business growth stage. Older firms are likely to be in a maturity stage, with stable cash flows, and 
therefore raise more debt.

Firm_size is the natural logarithm of a firm's total assets. Larger firms are likely to be more diversified, to bear lower bankruptcy risks, and to find an easier access to debt market as a result of their better reputation and greater tangible assets. According to the trade-off theory, a positive correlation with leverage is expected. Conversely, the pecking order hypothesis $(\mathrm{POH})$ predicts a negative relationship with leverage: larger and older firms are better known and could have had a history of retained earnings.

Cash: $\frac{\text { cash and equivalents }}{\text { total assets }}$. The higher the degree of liquidity, the lower the financing needs and the bankruptcy risks should be. According to the $\mathrm{POH}$, a negative relationship with leverage is expected as a result of available internal funds (at the apex of the hierarchy). Lower bankruptcy risks could lead to higher debt ratios according to the trade-off theory.

Market-to-book ratio is the natural logarithm of a firm's market-to-book ratio. It is a proxy for a firm's growth opportunities. Prevalent literature discusses and finds a negative correlation with leverage by relying on the trade-off theory. Several explanations are provided. First, firms with a higher market-to-book ratio are likely to show lower agency costs of free cash flow (Jensen, 1986). Second, a high market-to-book ratio could be due to a high incidence of intangible assets and related bankruptcy costs. Third, growth opportunities could lead to higher agency costs of debt as a result of asset substitution risks. The POH provides a different scenario: profitability being equal, firms with more investment opportunities should accumulate more debt over time. Thus, growth opportunities and leverage are positively related under the $\mathrm{POH}$.

Institutional is the percentage of shares held by institutional shareholders (banks, insurance companies, mutual funds, etc.). The stake held by institutional shareholders is a proxy for the relevance of outside blockholders. We only consider institutional investors that are not linked to the largest shareholder by syndicates. The expected link with leverage is negative: institutional investors are typically minority shareholders and may be concerned of being expropriated by the majority shareholders, especially when the separation between ownership and control is large.

Operating_leverage: $\frac{\text { depreciation }+ \text { labor cost }}{\text { sales }}$. This ratio expresses the incidence of fixed costs and, therefore, is a proxy for a company's operating income volatility. Firms with more volatile operating cash flows face higher expected costs of financial distress and should use less debt. Moreover, a more volatile operating income increases the probability that, in some scenarios, interest expense will exceed EBIT, therefore reducing tax benefits of debt. In addition, depreciation expense and labor cost are tax shields that substitute interest expenses. Thus, higher risk and non-debt tax shields should result in lower debt ratios under the trade-off theory. According to the $\mathrm{POH}$, higher risk implies higher adverse selection problems. So, under the $\mathrm{POH}$, the link with leverage should be positive.

Roa: $\frac{\text { ebit }}{\text { total assets }}$. According to the static trade-off theory, profitable firms face lower expected costs of financial distress and find interest tax shields more valuable. Thus, the tax and bankruptcy costs perspectives predict profitable firms to be more indebted. In addition, the agency costs perspective predicts that the discipline provided by debt is more valuable for profitable firms as these firms are likely to have severe free cash flow problems. In a dynamic trade-off model, leverage can appear to be negatively related to profitability due to various frictions (Kayhan \& Titman, 2007; Strebulaev, 2007). The POH argues that firms prefer internal funds over external funds. Investments and dividends being equal, more profitable firms will become less leveraged over time.

Tangible: $\frac{\text { tangible assets }}{\text { total assets }}$. Tangible assets, such as property, plant, and equipment, are easier for investors to value than intangibles, such as goodwill, patents, brands, etc. This decreases expected costs of financial distress. Furthermore, tangibility makes it unlikely for shareholders to face asset substitution problems. The lower 
expected costs of distress and fewer debt-related agency problems predict a positive relation between tangibility and leverage according to the trade-off theory. The POH makes opposite expectations. Low information asymmetry associated with tangible assets makes equity issuances less costly. Leverage ratios should therefore be lower for firms with higher tangibility.

Target is a dummy variable taking value 1 if the difference between the target leverage estimated as predicted values of Equation (1) and the observed levels of leverage is either lower than 10th percentile or higher than 90th percentile. This variable captures firms with suboptimal capital structures that should converge on the target more quickly under the trade-off theory. We argue that the larger the distance from the target leverage, the greater the costs of deviating from the target will be.

Tax_rate is the effective corporate tax rate measured as follows: $\frac{\text { tax expenses }}{\text { pre-tax profit }}$. According to the trade-off theory, firms paying a high amount of taxes want to reduce their taxable income by increasing deductible expenses, such as interests, in order to increase firm value. We therefore expect a positive relationship between the effective corporate tax rate and debt ratios.

\section{Results}

Table 1 provides descriptive statistics and the univariate analysis comparing family firms with non-family counterparts. As expected, family-controlled firms appear to use control-enhancing devices more extensively (higher votes-to-capital ratio), consistently with previous evidence outside Italy (e.g., Morck et al., 2005; Villalonga \& Amit, 2009). Moreover, family firms seem to be significantly more indebted than non-family ones (market_leverage). The univariate analysis also shows that family firms are less appealing to institutional investors (institutional), have poorer growth opportunities (market-to-book ratio), but have a better accounting-based performance (roa). They also have a lower operating risk (operating_leverage) and a lower effective corporate tax rate (tax_rate).

Table 1. Descriptive statistics ${ }^{\mathrm{a}}$

\begin{tabular}{lrrrrrrrrrrr}
\hline & \multicolumn{3}{c}{ Full sample } & \multicolumn{4}{c}{ Family firms (FF) } & \multicolumn{3}{c}{ Non-family firms (NFF) } \\
\cline { 2 - 12 } Variables & Mean & Median & \multicolumn{1}{c}{ SD } & Mean & Median & SD & Mean & Median & SD & FF - NFF \\
\hline market_leverage & 0.3215 & 0.2851 & 0.2420 & 0.3422 & 0.3057 & 0.2394 & 0.2896 & 0.2430 & 0.2429 & $0.0526^{* * * *}$ \\
family & 0.6061 & 1.0000 & 0.4889 & & & & & & & & \\
institutional & 0.0547 & 0.0232 & 0.1018 & 0.0349 & 0.0201 & 0.0462 & 0.0850 & 0.0415 & 0.1468 & $-0.0501^{* * * *}$ \\
votes-to-capital ratio & 1.2617 & 1.0000 & 0.6654 & 1.3263 & 1.0000 & 0.7988 & 1.1624 & 1.0000 & 0.3563 & $0.1639^{* * *}$ \\
firm_size & 13.1230 & 12.8900 & 1.8154 & 13.2760 & 13.0610 & 1.6656 & 12.8880 & 12.2320 & 2.0047 & $0.3880^{* * *}$ \\
market-to-book ratio & 0.5100 & 0.4447 & 0.6656 & 0.4614 & 0.3853 & 0.6858 & 0.5849 & 0.5710 & 0.6271 & $-0.1235^{* *}$ \\
roa & 0.0524 & 0.0576 & 0.0884 & 0.0672 & 0.0666 & 0.0652 & 0.0295 & 0.0421 & 0.1116 & $0.0377^{* * *}$ \\
tangible & 0.2381 & 0.1968 & 0.1887 & 0.2496 & 0.2160 & 0.1776 & 0.2204 & 0.1639 & 0.2037 & $0.0292^{* * *}$ \\
operating_leverage & 0.2750 & 0.2455 & 0.1398 & 0.2497 & 0.2345 & 0.1216 & 0.3138 & 0.2600 & 0.1564 & $-0.0641^{* * * *}$ \\
cash & 0.1399 & 0.0921 & 0.1408 & 0.1427 & 0.0903 & 0.1443 & 0.1355 & 0.1000 & 0.1353 & 0.0072 \\
firm_age & 3.3505 & 3.3673 & 0.9433 & 3.3913 & 3.4657 & 0.8758 & 3.2876 & 3.0910 & 1.0369 & 0.1037 \\
tax_rate & 0.4186 & 0.4133 & 0.1826 & 0.3877 & 0.3882 & 0.1708 & 0.4661 & 0.4540 & 0.1900 & $-0.0784^{* * * *}$ \\
\hline
\end{tabular}

${ }^{a}$ The table reports descriptive statistics (mean, median, and standard deviation) of the variables employed in the regressions for the entire sample, the subsample of family firms, and the subsample of non-family firms. FF - NFF reports the difference of means between family and non-family firms. t-test significance levels: * $(10 \%), * *(5 \%), * *(1 \%)$.

Pearson correlations (Table 2) do not show any multicollinearity problem among our independent and control variables. 
Table 2. Correlation matrix ${ }^{\mathrm{b}}$

\begin{tabular}{|c|c|c|c|c|c|c|c|c|c|c|c|c|}
\hline$\underline{\text { Variables }}$ & {$[\mathrm{A}]$} & {$[\mathrm{B}]$} & {$[\mathrm{C}]$} & [D] & {$[\mathrm{E}]$} & {$[\mathrm{F}]$} & [G] & {$[\mathrm{H}]$} & {$[\mathrm{I}]$} & {$[\mathrm{J}]$} & {$[\mathrm{K}]$} & {$[\mathrm{L}]$} \\
\hline [A] market_leverage & & 0.1062 & -0.0213 & 0.1293 & 0.4431 & -0.4906 & -0.1982 & 0.2322 & -0.2616 & -0.2976 & 0.4118 & 0.0892 \\
\hline [B] family & & 1 & -0.2403 & 0.1204 & 0.1043 & -0.0907 & 0.2092 & 0.0757 & -0.2243 & 0.0249 & 0.0538 & -0.2099 \\
\hline$[\mathrm{C}]$ institutional & & & 1 & -0.0281 & 0.0425 & 0.0435 & 0.0127 & 0.0218 & -0.0166 & -0.0968 & -0.0057 & 0.0327 \\
\hline [D] votes-to-capital ratio & & & & 1 & 0.3209 & -0.0111 & 0.0868 & 0.0602 & -0.0018 & -0.0102 & 0.1980 & -0.0538 \\
\hline [E] firm_size & & & & & 1 & -0.0845 & 0.1872 & 0.1288 & -0.2903 & -0.0910 & 0.4115 & -0.1733 \\
\hline$[\mathrm{F}]$ market-to-book ratio & & & & & & 1 & 0.1200 & -0.1257 & 0.2502 & 0.0294 & -0.3072 & -0.0062 \\
\hline$[\mathrm{G}]$ roa & & & & & & & 1 & 0.1163 & -0.2820 & 0.0773 & 0.0864 & -0.2004 \\
\hline$[\mathrm{H}]$ tangible & & & & & & & & 1 & 0.0571 & -0.3009 & 0.3257 & -0.0765 \\
\hline [I] operating_leverage & & & & & & & & & 1 & 0.1530 & -0.1479 & 0.1730 \\
\hline$[J]$ cash & & & & & & & & & & 1 & -0.2155 & -0.1675 \\
\hline$[\mathrm{K}]$ firm_age & & & & & & & & & & & 1 & -0.0755 \\
\hline$\underline{\text { L] }] \text { tax_rate }}$ & & & & & & & & & & & & 1 \\
\hline
\end{tabular}

Table 3 shows Equation (1) estimations by a fixed effects model. With reference to our independent variables, family and votes-to-capital ratio, estimated parameters point out that neither family nor votes-to-capital ratio, appear to be significantly linked to leverage. First, this means that, contrary to our Hypothesis 1, family firms are not significantly more leveraged than non-family counterparts; second, firms characterized by a higher separation between ownership and control, which therefore face more severe Type II agency costs, do not seem to exploit leverage to a greater extent. More interestingly, and consistently to our Hypothesis 2, family ownership moderates the relationship between leverage ratio and votes-to-capital ratio. In fact, the product term between family and votes-to-capital ratio is positive and statistically significant. This means that the relationship between leverage and separation is positive and statistically significant only in the subsample of family firms.

With reference to our control variables, the results are largely consistent with our expectations. According to the trade-off theory, leverage increases with firm size (firm_size) and the effective corporate tax rate (tax_rate); it decreases with the market-to-book ratio and the level of operating risk (operating_leverage). According to the $\mathrm{POH}$ and the dynamic trade-off model, leverage decreases with a firm's profitability (roa). Finally, as expected, the presence of institutional investors (institutional) is negatively related to leverage.

Table 3. Capital structure determinants ${ }^{\mathrm{c}}$

\begin{tabular}{|c|c|c|c|c|}
\hline \multirow[b]{2}{*}{ Variables } & \multicolumn{4}{|c|}{ Dependent variable: market_leverage } \\
\hline & (1) & (2) & (3) & (4) \\
\hline \multirow[t]{2}{*}{ family } & -0.0289 & -0.0168 & -0.0288 & -0.0167 \\
\hline & $(0.0441)$ & $(0.0433)$ & $(0.0438)$ & $(0.0430)$ \\
\hline \multirow[t]{2}{*}{ institutional } & $-0.1825^{* *}$ & $-0.1785^{* *}$ & $-0.1838 * *$ & $-0.1803^{* *}$ \\
\hline & $(0.0789)$ & $(0.0771)$ & $(0.0796)$ & $(0.0781)$ \\
\hline \multirow[t]{2}{*}{ votes-to-capital ratio } & 0.0279 & -0.0458 & 0.0284 & -0.0451 \\
\hline & $(0.0319)$ & $(0.0498)$ & $(0.0330)$ & $(0.0504)$ \\
\hline \multirow[t]{2}{*}{ firm_size } & $0.1406^{* * *}$ & $0.1388^{* * *}$ & $0.1406^{* * *}$ & $0.1388^{* * *}$ \\
\hline & $(0.0313)$ & $(0.0315)$ & $(0.0314)$ & $(0.0315)$ \\
\hline \multirow[t]{2}{*}{ market-to-book ratio } & $-0.1048 * * *$ & $-0.1053 * * *$ & $-0.1048^{* * *}$ & $-0.1053 * * *$ \\
\hline & $(0.0174)$ & $(0.0172)$ & $(0.0174)$ & $(0.0173)$ \\
\hline \multirow[t]{2}{*}{ roa } & $-0.3671 * * *$ & $-0.3531 * * *$ & $-0.3669^{* * *}$ & $-0.3529 * * *$ \\
\hline & $(0.1138)$ & $(0.1150)$ & $(0.1138)$ & $(0.1151)$ \\
\hline \multirow[t]{2}{*}{ tangible } & -0.0570 & -0.0124 & -0.0571 & -0.0125 \\
\hline & $(0.1190)$ & $(0.1223)$ & $(0.1192)$ & $(0.1225)$ \\
\hline \multirow[t]{2}{*}{ operating_leverage } & $-0.2314 *$ & $-0.2250^{*}$ & $-0.2312 *$ & $-0.2248 *$ \\
\hline & $(0.1298)$ & $(0.1289)$ & (0.1299) & $(0.1290)$ \\
\hline \multirow[t]{2}{*}{ cash } & -0.1234 & -0.1180 & -0.1234 & -0.1179 \\
\hline & $(0.0950)$ & $(0.0962)$ & (0.0949) & $(0.0962)$ \\
\hline \multirow[t]{2}{*}{ firm_age } & 0.0521 & 0.0406 & 0.0522 & 0.0406 \\
\hline & $(0.0413)$ & $(0.0399)$ & $(0.0413)$ & $(0.0399)$ \\
\hline
\end{tabular}




\begin{tabular}{lcccc}
\hline tax_rate & $0.0598^{* *}$ & $0.0618^{* *}$ & $0.0599 * *$ & $0.0618^{* *}$ \\
& $(0.0258)$ & $(0.0256)$ & $(0.0258)$ & $(0.0256)$ \\
family*votes-to-capital ratio & & $0.1011^{* *}$ & & $0.1012^{* *}$ \\
& & $(0.0461)$ & & $(0.0460)$ \\
institutional*votes-to-capital ratio & & & -0.0116 & -0.0164 \\
& & & $(0.1682)$ & $(0.1674)$ \\
R-squared & 0.8860 & 0.8868 & 0.8860 & 0.8868 \\
Adjusted R-squared & 0.8636 & 0.8643 & 0.8633 & 0.8641 \\
Observations & 749 & 749 & 749 & 749 \\
\hline
\end{tabular}

${ }^{\mathrm{c}}$ The table reports estimations of Equation (1) by a fixed effects model. All regressions include time dummies. HAC standard errors are in parentheses. Significance levels: * $(10 \%), * *(5 \%), * * *(1 \%)$.

Moving on to the estimation of the speed of adjustment by GMM-SYS estimator (Table 4), the coefficient of the lagged dependent variable, which indicates the speed of adjustment, in all models of Table 4, is as much as 0.65-0.60, which corresponds to a half-life of about 1.35 years (Note 4). The average firm in the sample closes about $35-40 \%$ of the gap between past and desired level of leverage within one year. According to our Hypothesis 3, family firms adjust their leverage ratio towards the target more slowly. In fact, Models (5) and (6) of Table 4 show estimations of the interaction term defined as product between market_leverage (-1) and family. The coefficient of the interaction variable is positive and statistically significant. For example, Model (5) of Table 4 points out that non-family firms close about $43 \%$ of the gap between past and desired level of leverage within one year (1-0.5707). In family firms, the gap closed within one year is about $34 \%$ (1-0.5707-0.0835).

Regarding to our independent and control variables, it is worth noticing that family and votes-to-capital ratio turn to be statistically significant in Table 4 . This evidence may appear in contrast to the results found in Table 3 . The main explanation of this apparently inconsistent result resides in the estimator properties. The fixed effects model presented in Table 3 does not permit the inclusion of time invariant independent variables. In our case, family is almost always constant over time because the controlling family is reluctant to give up control to non-family shareholders. Therefore its coefficient cannot be reliably estimated by the fixed effects model.

Table 4. Capital structure determinants and the estimation of the speed of adjustment ${ }^{\mathrm{d}}$

\begin{tabular}{|c|c|c|c|c|c|c|}
\hline \multirow[b]{2}{*}{ Variables } & \multicolumn{6}{|c|}{ Dependent variable: market_leverage } \\
\hline & $(1)$ & $(2)$ & $(3)$ & $(4)$ & $(5)$ & $(6)$ \\
\hline \multirow[t]{2}{*}{ market_leverage (-1) } & $0.6616^{* * * *}$ & $0.6732 * * *$ & $0.6163 * * *$ & $0.6137 * * *$ & $0.5707 * * *$ & $0.6149 * * *$ \\
\hline & $(0.0164)$ & $(0.0168)$ & $(0.0140)$ & $(0.0143)$ & $(0.0288)$ & $(0.0338)$ \\
\hline \multirow[t]{2}{*}{ family } & $0.0200 * * *$ & $0.0214 * * *$ & $0.0123 * *$ & $0.0134 * *$ & -0.0130 & -0.0089 \\
\hline & $(0.0051)$ & $(0.0050)$ & $(0.0054)$ & $(0.0054)$ & $(0.0134)$ & $(0.0143)$ \\
\hline \multirow[t]{2}{*}{ institutional } & $-0.0720 * * *$ & $-0.0744 * * *$ & $-0.2763 * * *$ & $-0.2885 * * *$ & $-0.2259 * * *$ & $-0.2368 * * *$ \\
\hline & $(0.0141)$ & $(0.0137)$ & $(0.0344)$ & $(0.0353)$ & $(0.0397)$ & $(0.0386)$ \\
\hline \multirow[t]{2}{*}{ votes-to-capital ratio } & -0.0028 & $-0.0169 * *$ & 0.0011 & $-0.0219 * * *$ & $-0.0309 * * *$ & $-0.0273 * * *$ \\
\hline & $(0.0037)$ & $(0.0077)$ & $(0.0052)$ & $(0.0081)$ & $(0.0081)$ & $(0.0082)$ \\
\hline \multirow[t]{2}{*}{ firm_size } & $0.0204 * * *$ & $0.0193 * * *$ & $0.0216^{* * *}$ & $0.0219 * * *$ & $0.0234 * * *$ & $0.0219 * * *$ \\
\hline & $(0.0023)$ & $(0.0022)$ & $(0.0021)$ & $(0.0022)$ & $(0.0021)$ & $(0.0021)$ \\
\hline \multirow[t]{2}{*}{ market-to-book ratio } & $-0.0667 * * *$ & $-0.0659 * * *$ & $-0.0703 * * *$ & $-0.0704 * * *$ & $-0.0673 * * *$ & $-0.0659 * * *$ \\
\hline & $(0.0042)$ & $(0.0041)$ & $(0.0030)$ & $(0.0030)$ & $(0.0035)$ & $(0.0039)$ \\
\hline \multirow[t]{2}{*}{ roa } & $-0.3820 * * *$ & $-0.3636 * * *$ & $-0.3706^{* * * *}$ & $-0.3662 * * *$ & $-0.3406^{* * *} *$ & $-0.3392 * * *$ \\
\hline & $(0.0251)$ & $(0.0248)$ & $(0.0205)$ & $(0.0209)$ & $(0.0110)$ & $(0.0222)$ \\
\hline \multirow[t]{2}{*}{ tangible } & $0.0418 * * *$ & $0.0437 * * *$ & $0.0541 * * *$ & $0.0580 * * *$ & $0.0661 * * *$ & $0.0479 * * *$ \\
\hline & $(0.0154)$ & $(0.0165)$ & $(0.0151)$ & $(0.0155)$ & $(0.0159)$ & $(0.0165)$ \\
\hline \multirow[t]{2}{*}{ operating_leverage } & $-0.0322 *$ & -0.0270 & $-0.0685 * * *$ & $-0.0701 * * *$ & $-0.0535 * * *$ & $-0.0461 * * *$ \\
\hline & $(0.0169)$ & $(0.0167)$ & $(0.0120)$ & $(0.0119)$ & $(0.0131)$ & $(0.0125)$ \\
\hline \multirow[t]{2}{*}{ cash } & $-0.0922 * * *$ & $-0.0869 * * *$ & $-0.1148 * * *$ & $-0.1144 * * *$ & $-0.1223 * * *$ & $-0.1208 * * *$ \\
\hline & $(0.0170)$ & $(0.0175)$ & $(0.0158)$ & $(0.0159)$ & $(0.0161)$ & $(0.0162)$ \\
\hline \multirow[t]{2}{*}{ firm_age } & -0.0004 & -0.0008 & 0.0014 & 0.0008 & -0.0002 & 0.0002 \\
\hline & $(0.0031)$ & $(0.0030)$ & $(0.0028)$ & $(0.0029)$ & $(0.0030)$ & $(0-0029)$ \\
\hline tax_rate & $0.0632 * * *$ & $0.0607 * * *$ & $0.0693 * * *$ & $0.0693 * * *$ & $0.0680 * * *$ & $0.0665^{* * *}$ \\
\hline
\end{tabular}




\begin{tabular}{|c|c|c|c|c|c|c|}
\hline & $(0.0086)$ & $(0.0087)$ & $(0.0077)$ & $(0.0075)$ & $(0.0078)$ & $(0.0075)$ \\
\hline \multirow[t]{2}{*}{ family*votes-to-capital ratio } & & $0.0181 * *$ & & $0.0244 * * *$ & $0.0364 * * *$ & $0.0290 * * *$ \\
\hline & & $(0.0076)$ & & $(0.0066)$ & $(0.0057)$ & $(0.0060)$ \\
\hline \multirow{2}{*}{ institutional*votes-to-capital ratio } & & & -0.0900 & -0.0826 & 0.0103 & -0.0096 \\
\hline & & & $(0.0725)$ & $(0.0719)$ & $(0.0749)$ & $(0.0725)$ \\
\hline \multirow[t]{2}{*}{ market_leverage $(-1) *$ family } & & & & & $0.0835^{* *}$ & $0.0699 *$ \\
\hline & & & & & $(0.0361)$ & $(0.0390)$ \\
\hline \multirow[t]{2}{*}{ market_leverage $(-1)^{*}$ target } & & & & & & $-0.0892 * * *$ \\
\hline & & & & & & $(0.0237)$ \\
\hline \multirow[t]{2}{*}{ target } & & & & & & $0.0280 * * *$ \\
\hline & & & & & & $(0.0085)$ \\
\hline \multirow[t]{2}{*}{ Observations } & 642 & 642 & 642 & 642 & 642 & 642 \\
\hline & -3.7802 & & -3.8705 & & -3.7829 & -3.9587 \\
\hline \multirow[t]{2}{*}{ Test for AR(1) errors } & $(0.0002)$ & $-3.7001(0.0002)$ & $(0.0001)$ & $-3.7633(0.0002)$ & $(0.0002)$ & $(0.0001)$ \\
\hline & -1.0332 & & -0.9513 & & -0.9681 & -0.9612 \\
\hline \multirow[t]{2}{*}{ Test for $\operatorname{AR}(2)$ errors } & $(0.3015)$ & $-1.0215(0.3070)$ & $(0.3415)$ & $-0.8999(0.3682)$ & $(0.3330)$ & $(0.3364)$ \\
\hline & 76.548 & & 81.0854 & & 82.7742 & 81.1961 \\
\hline \multirow[t]{2}{*}{ Sargan test } & $(0.3654)$ & 77.247 (0.4386) & $(0.6001)$ & $81.0352(0.6016)$ & $(0.5174)$ & $(0.5043)$ \\
\hline & & & 21349.1 & & 26788 & \\
\hline \multirow[t]{2}{*}{ Wald (joint) test } & $16742(0.0000)$ & $19192.9(0.0000)$ & $(0.0000)$ & $23034.7(0.0000)$ & $(0.0000)$ & $31362(0.0000)$ \\
\hline & 534.741 & & 991.519 & & 770.991 & 441.506 \\
\hline Wald (time dummies) & $(0.0000)$ & $524.682(0.0000)$ & $(0.0000)$ & $911.177(0.0000)$ & $(0.0000)$ & $(0.0000)$ \\
\hline
\end{tabular}

${ }^{\mathrm{d}}$ The table reports estimations of Equation (3) by GMM-SYS (Blundell and Bond, 1998). All regressions include time dummies. Asymptotic standard errors that are robust to heteroskedasticity and small sample bias are given in parentheses under the coefficients. AR(1) errors and $\operatorname{AR}(2)$ errors are the first- and second-order autocorrelations of residuals, which are asymptotically distributed as $\mathrm{N}(0,1)$ under the null hypothesis of no serial correlation (in parentheses, the p-value of the test statistic). Sargan test is a test of the over identifying restrictions, asymptotically distributed as $\chi^{2}$ (df) under the null hypothesis of the instruments validity (in parentheses, the p-value of the test statistic). The Wald statistics test the joint significance of estimated coefficients, asymptotically distributed as $\chi^{2}$ (df) under the null hypothesis of no relation (in parentheses, the p-value of the test statistic). Significance levels: * $(10 \%)$, ** (5\%), *** (1\%).

The same problem does not affect the variable votes-to-capital ratio which experiences small changes over time as a result of ownership structure modifications. On the contrary, GMM-SYS estimator presented in Table 4 also allows time invariant independent variables to be included and consistently estimated. Therefore, results in Table 4 support Hypothesis 1, according to which family firms are significantly more indebted than non-family counterparts, and confirm Hypothesis 2, which claims a positive relationship between separation and leverage but only in family firms. Control variables are largely consistent with the results already shown in Table 3. In Table 4, we also allow for the different converging paths depending on the presence of deviations from the target leverage. The interaction variable expressed as product between target and market_leverage (-1) allows us to distinguish the different speed between firms with extreme leverage ratios (underleveraged and overleveraged firms) and firms with debt levels nearer to the target. As expected, Model (6) of Table 4 suggests a negative and statistically significant coefficient for the interaction term. Firms with capital structures departing from the target struggle to converge on it at a faster pace.

The speed of adjustment is also estimated by the LD estimator that fits well persistent data series and short sample periods such as ours. Table 5 reports estimations of the LD estimator in the form of Equation (5) using two differencing lengths, $\mathrm{k}=3$ and $\mathrm{k}=4$. The values reported in Table 5 result from the third iteration of Equation (5). The evidence shows that the speed of adjustment goes down (now it is about 24\%), therefore confirming the fact that GMM-SYS estimator tends to be biased upwards (Huang \& Ritter, 2009). 
Table 5. Capital structure determinants and the estimation of the speed of adjustment: The long difference instrumental variables estimator ${ }^{\mathrm{e}}$

\begin{tabular}{|c|c|c|}
\hline \multirow[b]{2}{*}{ Variables } & \multicolumn{2}{|c|}{ Dependent variable: $\Delta$ market_leverage $\mathrm{t}_{\mathrm{t}, \mathrm{-k}}$} \\
\hline & (1) $\mathrm{k}=3$ & (2) $\mathrm{k}=4$ \\
\hline \multirow[t]{2}{*}{$\Delta$ market_leverage $\mathrm{t}_{\mathrm{t}-1, \mathrm{t}-\mathrm{k}-\mathrm{l}}$} & $0.7699 * * *$ & $0.7578 * * *$ \\
\hline & $(0.1374)$ & $(0.0955)$ \\
\hline \multirow[t]{2}{*}{$\Delta$ family $_{\mathrm{t},-\mathrm{k}}$} & $0.0515^{*}$ & 0.0143 \\
\hline & $(0.0289)$ & $(0.0402)$ \\
\hline \multirow[t]{2}{*}{$\Delta$ institutional $\mathrm{l}_{\mathrm{t}, \mathrm{t}-\mathrm{k}}$} & 0.0572 & 0.0434 \\
\hline & $(0.0941)$ & $(0.1024)$ \\
\hline \multirow[t]{2}{*}{$\Delta$ votes-to-capital ratio ${ }_{\mathrm{t},-\mathrm{k}}$} & $0.1230 * *$ & $0.1152 * *$ \\
\hline & $(0.0592)$ & $(0.0505)$ \\
\hline \multirow[t]{2}{*}{$\Delta$ firm_size $\mathrm{t}_{\mathrm{t}, \mathrm{-k}}$} & $0.0934 * * *$ & $0.0765 * * *$ \\
\hline & $(0.0260)$ & $(0.0275)$ \\
\hline \multirow[t]{2}{*}{$\Delta$ market-to-book ratio $\mathrm{t}_{\mathrm{t}, \mathrm{k}}$} & $-0.1046 * * *$ & $-0.0945 * * *$ \\
\hline & $(0.0195)$ & $(0.0217)$ \\
\hline \multirow[t]{2}{*}{$\Delta \mathrm{roa}_{\mathrm{t}, \mathrm{t}-\mathrm{k}}$} & $-0.3909 * * *$ & $-0.2524 * * *$ \\
\hline & $(0.1167)$ & $(0.0877)$ \\
\hline \multirow[t]{2}{*}{$\Delta$ tangible $_{\mathrm{t}, \mathrm{t}-\mathrm{k}}$} & -0.0363 & -0.0818 \\
\hline & $(0.0810)$ & $(0.0994)$ \\
\hline \multirow[t]{2}{*}{$\Delta$ operating_leverage $\mathrm{t}_{\mathrm{t},-\mathrm{k}}$} & $-0.3264 * * *$ & $-0.2666 * *$ \\
\hline & $(0.1151)$ & $(0.1265)$ \\
\hline \multirow[t]{2}{*}{$\Delta \operatorname{cash}_{\mathrm{t}, \mathrm{t}-\mathrm{k}}$} & -0.0910 & $-0.3236^{* *}$ \\
\hline & $(0.1202)$ & $(0.1347)$ \\
\hline \multirow[t]{2}{*}{$\Delta$ firm_age $e_{t,-1-k}$} & $-0.1079 * * *$ & $-0.1111 * * *$ \\
\hline & $(0.0336)$ & $(0.0285)$ \\
\hline \multirow[t]{2}{*}{$\Delta$ tax_rate $_{\mathrm{t}, \mathrm{t}-\mathrm{k}}$} & 0.0504 & $0.1483 * * *$ \\
\hline & $(0.0464)$ & $(0.0523)$ \\
\hline R-squared & 0.5676 & 0.6430 \\
\hline Adjusted R-squared & 0.5522 & 0.6236 \\
\hline Observations & 321 & 214 \\
\hline
\end{tabular}

${ }^{\mathrm{e}}$ The table reports estimations of Equation (5) by the long difference instrumental variables estimator. The differencing length is $\mathrm{k}=3$ (Model 1) and $\mathrm{k}=4$ (Model 2). All regressions include time dummies. HAC standard errors are in parentheses. Significance levels: * $(10 \%)$, ** (5\%), *** $(1 \%)$.

Finally, as robustness check, we also estimate the speed of adjustment by using OLS regressions and fixed effects model (Table 6). According to Bond (2002), the coefficient of the lagged dependent variable should always lie between the upper bound given by fixed effects estimations and the lower bound given by OLS estimations. LD and GMM-SYS estimator results appear to be consistent with Bond (2002).

\section{Discussion and Conclusion}

By relying on the agency theoretical model, our study examines the relationship between family ownership and debt financing both in a statistic and dynamic context. Since the analysis is performed in Italy, we try to disentangle the family ownership effect on leverage ratio from the effect related to the presence of separation between voting rights and cash flow rights. We also try to show potential interactions between the two characters. Extant literature focuses on both characteristics separately and overlooks the fact that, first, separation between ownership and control may be a factor that tilts the relationship between family ownership and leverage, second, the family character of ownership may affect the relationship between separation and debt ratio. 
Table 6. Capital structure determinants and the estimation of the speed of adjustment by OLS and fixed effects model $^{\mathrm{f}}$

\begin{tabular}{|c|c|c|}
\hline \multirow[b]{2}{*}{ Variables } & \multicolumn{2}{|c|}{ Dependent variable: market_leverage } \\
\hline & $(1)$ & $(2)$ \\
\hline \multirow[t]{2}{*}{ market_leverage (-1) } & $0.7953^{* * *}$ & $0.4747 * * *$ \\
\hline & $(0.0234)$ & $(0.0647)$ \\
\hline \multirow[t]{2}{*}{ family } & $0.0207 * *$ & 0.0114 \\
\hline & $(0.0084)$ & $(0.0385)$ \\
\hline \multirow[t]{2}{*}{ institutional } & -0.0609 & -0.0670 \\
\hline & $(0.0451)$ & $(0.0867)$ \\
\hline \multirow[t]{2}{*}{ votes-to-capital ratio } & -0.0040 & $0.0649 *$ \\
\hline & $(0.0041)$ & $(0.0339)$ \\
\hline \multirow[t]{2}{*}{ firm_size } & $0.0103^{* * *}$ & $0.1224 * * *$ \\
\hline & $(0.0024)$ & $(0.0284)$ \\
\hline \multirow[t]{2}{*}{ market-to-book ratio } & $-0.0356^{* * *}$ & $-0.0966 * * *$ \\
\hline & $(0.0069)$ & $(0.0170)$ \\
\hline \multirow[t]{2}{*}{ roa } & $-0.3034 * * *$ & $-0.3902 * * *$ \\
\hline & $(0.0673)$ & $(0.1100)$ \\
\hline \multirow[t]{2}{*}{ tangible } & 0.0113 & -0.0320 \\
\hline & $(0.0214)$ & $(0.0887)$ \\
\hline \multirow[t]{2}{*}{ operating_leverage } & -0.0212 & $-0.2491 * *$ \\
\hline & $(0.0307)$ & $(0.1081)$ \\
\hline \multirow[t]{2}{*}{ cash } & $-0.0943 * * *$ & -0.1315 \\
\hline & $(0.0250)$ & $(0.1146)$ \\
\hline \multirow[t]{2}{*}{ firm_age } & -0.0009 & 0.0511 \\
\hline & $(0.0039)$ & $(0.0373)$ \\
\hline \multirow[t]{2}{*}{ tax_rate } & $0.0623^{* * *}$ & 0.0391 \\
\hline & $(0.0200)$ & $(0.0265)$ \\
\hline R-squared & 0.8713 & 0.9212 \\
\hline Adjusted R-squared & 0.8678 & 0.9025 \\
\hline Observations & 642 & 642 \\
\hline
\end{tabular}

${ }_{\mathrm{f}}^{\mathrm{f}}$ The table reports estimations of Equation (3) by OLS (Model 1) and fixed effects model (Model 2). All regressions include time dummies. HAC standard errors are in parentheses. Significance levels: * $(10 \%), * *(5 \%), * * *(1 \%)$.

In line with our Hypothesis 1, we find that family firms are more indebted than non-family counterparts. Family firms seem to exploit debt to a greater extent in order to hold control in a country characterized by high private benefits of control and the inclination of family firms to make large use of control-enhancing devices. Besides, family firms are likely to find debt financing less costly as a result of the strong ties between family owners and banks, that reduce agency conflicts between creditors and shareholders as opposed to the higher Type II agency problems that make equity financing more expensive. Debt allows the business to grow without forcing the controlling family to have to deal with control dilution problems. More importantly, even in case of bankruptcy of a highly leveraged operating unit, the large use of pyramidal structures, together with the limited liability of the holding company, allow the controlling family to maintain the control of the group and to bear only a small portion of the wealth destruction. The higher leverage in family-owned listed firms is consistent with previous studies that rely on the agency approach (e.g., Harijono et al., 2004; King \& Santor, 2008).

We further assume that family ownership may moderate the relationship between separation and leverage because the higher inclination of family owners to divert wealth at the expense of minority shareholders may induce them to exploit leverage to a greater extent as a mechanism to inflate assets under domination, especially when the share of cash flow rights is disproportionately lower than the share of voting rights. According to Hypothesis 2, we find that separation between voting rights and cash flow rights is positively related to leverage if and only if the controlling shareholder is a family. Most studies that examine the relationship between separation and leverage link it to the quality of capital market scrutiny (e.g., Faccio et al., 2007 and 2010; Paligorova \& Xu, 2012). We add a piece to the puzzle: the higher leverage in firms characterized by high separation may also be related to the fact that most of the firms employing control-enhancing devices are controlled by a family, more inclined to acquire private benefits through debt-inflated assets. Conversely, 
non-family firms do not seem to show any expropriation risk through debt: higher separation between ownership and control leads to lower debt ratios. From the demand side, non-family shareholders are less inclined to divert assets at the expense of minority shareholders and, therefore, non-family firms' debt reliance is lower. From the supply side, non-family firms can negotiate with creditors to a lesser extent than family firms due to missing or insufficient relationships and connections; this causes lenders to require lower debt levels or impose tighter credit conditions when expropriation risks increase.

Within a dynamic context, family ownership may also influence the adaptation of debt levels to the extent that it affects the adjustment costs and the costs of deviating from the target leverage. Under our assumptions, family firms should bear higher adjustment costs because poor Type II agency relationships make access to public capital markets more difficult and expensive; vice versa, the costs of deviating from the target leverage should be lower. In fact, trust-based and long-lasting relationships between family owners and banks make deviations from the target leverage more negotiable without an immediate market penalty. Consistent with our Hypothesis 3 , we find that family firms rebalance their leverage ratio towards the target at a slower pace than non-family counterparts. This evidence, to the best of our knowledge, is the first contribution to the research stream of dynamic capital structure and the determinants of the speed of adjustment. We find a speed of adjustment of about $35-40 \%$ for the entire sample, $43 \%$ for non-family firms, and $34 \%$ for family firms. The speed of adjustment for the whole sample decreases to about $24 \%$ by using the LD estimator.

Our study advances the literature on family business financing decisions in several ways. First of all, we lend further support to previous studies claiming that family owners of listed firms may desire to hold control and to appropriate wealth at the expense of minority shareholders by means of debt (e.g., Wiwattanakantang, 1999; Harijono et al., 2004; King \& Santor, 2008). Second, we propose a further explanation of why firms having cash flow rights that deviate from voting rights may tend to be more leveraged (e.g., Faccio et al., 2007, 2010; Paligorova \& Xu, 2012). Third, we demonstrate that family firms tend not to follow models of optimal leverage when choosing their capital structure in the sense that capital structure adjustments towards the optimal level take place more infrequently than they do in non-family firms.

\section{References}

Aganin, A., \& Volpin, P. F. (2003). History of corporate ownership in Italy. Finance Working Paper 17, European Corporate Governance Institute. http://dx.doi.org/10.2139/ssrn.391180

Anderson, R. C., \& Reeb, D. M. (2004). Board composition: Balancing family influence in S\&P 500 firms. Administrative Science Quarterly, 49(2), 209-237.

Anderson, R. C., Duru, A., \& Reeb, D. M. (2009). Founders, heirs, and corporate opacity in the United States. Journal of Financial Economics, 92(2), 205-222. http://dx.doi.org/10.1016/j.jfineco.2008.04.006

Anderson, R. C., Mansi, S. A., \& Reeb, D. M. (2003). Founding family ownership and the agency cost of debt. Journal of Financial Economics, 68, 263-285. http://dx.doi.org/10.1016/S0304-405X(03)00067-9

Bebchuk, L. A., Kraakman, R., \& Triantis, G. (2000). Stock pyramids, cross-ownership, and dual class equity: The mechanisms and agency costs of separating control from cash-flow rights. In R. K. Morck (Ed.), Concentrated corporate ownership (pp. 295-318). Chicago: University of Chicago Press.

Bennedsen, M., Perez-Gonzalez, F., \& Wolfenzon, D. (2010). The governance of family firms. In R. Anderson, \& K. H. Baker (Eds.), Corporate governance: A synthesis of theory, research, and practice (pp. 371-390). Hoboken, NJ: John Wiley \& Sons. http://dx.doi.org/10.1002/9781118258439.ch19

Bianchi, M., \& Bianco, M. (2006). Italian corporate governance in the last 15 years: From pyramids to coalitions? Finance Working Paper 144, European Corporate Governance Institute.

Bianchi, M., Bianco, M., \& Enriques, L. (2001). Pyramidal groups and the separation between ownership and control in Italy. In F. Barca, \& M. Becht (Eds.), The control of corporate Europe (pp. 154-186). New York: Oxford University Press.

Bianco, M., \& Nicodano, G. (2006). Pyramidal groups and debt. European Economic Review, 50, 937-961. http://dx.doi.org/10.1016/j.euroecorev.2004.11.001

Blundell, R. W., \& Bond, S. (1998). Initial conditions and moment restrictions in dynamic panel data models. Journal of Econometrics, 87, 115-143. http://dx.doi.org/10.1016/S0304-4076(98)00009-8

Bond, S. (2002). Dynamic panel data models: A guide to micro data methods and practice. CEMMAP working paper, CWP09/02. http://dx.doi.org/10.1007/s10258-002-0009-9 
Burkart, M., Panunzi, F., \& Shleifer, A. (2003). Family firms. Journal of Finance, 58(5), 2167-2202. http://dx.doi.org/10.1111/1540-6261.00601

Caprio, L., \& Croci, E. (2008). The determinants of the voting premium in Italy: The evidence from 1974 to 2003. Journal of Banking and Finance, 32(11), 2433-2443. http://dx.doi.org/10.1016/j.jbankfin.2008.04.001

Casson, M. (1999). The economics of the family firm. Scandinavian Economic History Review, 47(1), 10-23. http://dx.doi.org/10.1080/03585522.1999.10419802

Chami, R. (2001). What is different about family businesses. International Monetary Fund Working Papers, No. 01/70. http://dx.doi.org/10.5089/9781451849158.001

Driffield, N., Mahambare, V., \& Pal, S. (2007). How does ownership structure affect capital structure and firm value? Recent evidence from East Asia. Economics of Transition, 15(3), 535-573. http://dx.doi.org/10.1111/j.1468-0351.2007.00291.x

Drobetz, W., \& Schilling, D. (2012). Heterogeneity in the speed of adjustment of leverage ratios. FMA European Conference paper, Istanbul.

Dyck, A., \& Zingales, L. (2004). Private benefits of control: An international comparison. Journal of Finance, 59(2), 537-600. http://dx.doi.org/10.1111/j.1540-6261.2004.00642.x

Ellul, A., Guntay, L., \& Lel, U. (2007). External governance and debt agency costs of family firms. Board of Governors of the Federal Reserve System, International Finance Discussion Papers, No. 908.

Faccio, M., \& Lang, L. H. P. (2002). The ultimate ownership of western European corporations. Journal of Financial Economics, 65(3), 365-395. http://dx.doi.org/10.1016/S0304-405X(02)00146-0

Faccio, M., Lang, L. H. P., \& Young, L. (2001). Dividends and expropriation. American Economic Review, 91(1), 54-78. http://dx.doi.org/10.1257/aer.91.1.54

Faccio, M., Lang, L. H. P., \& Young, L. (2007). Debt and expropriation. Purdue CIBER working papers, No. 50.

Faccio, M., Lang, L. H. P., \& Young, L. (2010). Pyramiding vs. leverage in corporate groups: International evidence. Journal of International Business Studies, 4l(1), 88-104. http://dx.doi.org/10.1057/jibs.2009.33

Filatotchev, I., \& Mickiewicz, T. (2006). Ownership concentration, private benefits of control and debt financing. In T. Mickiewicz (Ed.), Corporate governance and finance in Poland and Russia (pp. 159-176). Houndmills: Palgrave Macmillan.

Flannery, M. J., \& Hankins, K. W. (2013). Estimating dynamic panel models in corporate finance. Journal of Corporate Finance, 19, 1-19. http://dx.doi.org/10.1016/j.jcorpfin.2012.09.004

Flannery, M. J., \& Rangan, K. (2006). Partial adjustment towards target capital structures. Journal of Financial Economics, 79, 469-506. http://dx.doi.org/10.1016/j.jfineco.2005.03.004

Hahn, J., Hausman, J., \& Kuersteiner, G. (2007). Long difference instrumental variables estimation for dynamic panel models with fixed effects. Journal of Econometrics, 140, 574-617. http://dx.doi.org/10.1016/j.jeconom.2006.07.005

Harijono, H., Ariff, M., \& Tanewski, G. A. (2004). The impact of family control of firms on leverage: Australian evidence. EFMA Basel meeting paper. http://dx.doi.org/10.2139/ssrn.487706

Huang, R., \& Ritter, J. R. (2009). Testing theories of capital structure and estimating the speed of adjustment. Journal of Financial and Quantitative Analysis, 44(2), 237-271. http://dx.doi.org/10.1017/S0022109009090152

Hutchinson, R. W. (1995). The capital structure and investment decision of the small owner-managed firm: Some exploratory issues. Small Business Economics, 7, 231-239. http://dx.doi.org/10.1007/BF01135368

Jensen, M. C. (1986). Agency costs of free cash flow, corporate finance, and takeovers. American Economic Review, 76, 323-329.

Kayhan, A., \& Titman, S. (2007). Firms' histories and their capital structures. Journal of Financial Economics, 83, 1-32. http://dx.doi.org/10.1016/j.jfineco.2005.10.007

King, M. R., \& Santor, E. (2008). Family values: Ownership structure, performance and capital structure of

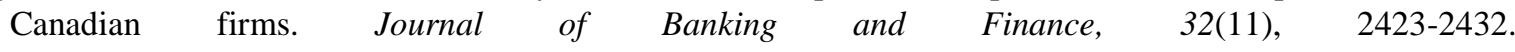
http://dx.doi.org/10.1016/j.jbankfin.2008.02.002 
La Porta, R., Lopez-de-Silanes, F., \& Shleifer, A. (1999). Corporate ownership around the world. Journal of Finance, 54(2), 471-517. http://dx.doi.org/10.1111/0022-1082.00115

Lemmon, M. L., Roberts, M. R., \& Zender, J. F. (2008). Back to the beginning: Persistence and the cross-section of corporate capital structure. Journal of Finance, 63(4), 1575-1608. http://dx.doi.org/10.1111/j.1540-6261.2008.01369.x

Leontief, W. W. (1986). Input-output economics. New York: Oxford University Press.

Mengoli, S., Pazzaglia, F., \& Sapienza, E. (2009). Effect of governance reforms on corporate ownership in Italy: Is it still Pizza, Spaghetti and Mandolino? Corporate Governance An International Review, 17(5), 629-645. http://dx.doi.org/10.1111/j.1467-8683.2009.00752.x

Mishra, C. S., \& McConaughy, D. L. (1999). Founding-family control and capital structure: The risk of loss of control and the aversion to debt. Entrepreneurship Theory and Practice, 23, 53-64.

Morck, R. K., Wolfenzon, D., \& Yeung, B. (2005). Corporate governance, economic entrenchment, and growth. Journal of Economic Literature, 43(3), 655-720. http://dx.doi.org/10.1257/002205105774431252

Nenova, T. (2003). The value of corporate voting rights and control: A cross-country analysis. Journal of Financial Economics, 68(3), 325-351. http://dx.doi.org/10.1016/S0304-405X(03)00069-2

Paligorova, T., \& Xu, Z. (2012). Complex ownership and capital structure. Journal of Corporate Finance, 18(4), 701-716. http://dx.doi.org/10.1016/j.jcorpfin.2012.05.001

Poutziouris, P., Chittenden, F., \& Michaelas, N. (1998). The financial affairs of private companies. Manchester: Manchester Business School, The University of Manchester.

Romano, C. A., Tanewski, G. A., \& Smyrnios, K. X. (2001). Capital structure decision making: A model for family business, Journal of Business Venturing, 16(3), 285-310. http://dx.doi.org/10.1016/S0883-9026(99)00053-1

Santella, P., Drago, C., \& Polo, A. (2007). The Italian chamber of lords sits on listed company boards. An empirical analysis of Italian listed company boards from 1998 to 2006. MPRA working paper.

Shleifer, A., \& Vishny, R. W. (1997). A survey of corporate governance. Journal of Finance, 52(2), 737-783. http://dx.doi.org/10.1111/j.1540-6261.1997.tb04820.x

Steijvers, T., \& Voordeckers, W. (2009). Private family ownership and the agency costs of debt. Family Business Review, 22(4), 333-346. http://dx.doi.org/10.1177/0894486509338291

Strebulaev, I. (2007). Do tests of capital structure theory mean what they say? Journal of Finance, 62, 1747-1787. http://dx.doi.org/10.1111/j.1540-6261.2007.01256.x

Villalonga, B., \& Amit, R. (2009). How are US family firms controlled? Review of Financial Studies, 22(8), 3047-3091. http://dx.doi.org/10.1093/rfs/hhn080

Wiwattanakantang, Y. (1999). An empirical study on the determinants of the capital structure of Thai firms. Pacific-Basin Finance Journal, 7, 371-403. http://dx.doi.org/10.1016/S0927-538X(99)00007-4

\section{Notes}

Note 1. Hereafter, the lagged value of each variable will be indicated as follows: VARIABLE NAME (-k), where $\mathrm{k}$ indicates the number of lags. For example, market_leverage (-1) indicates the variable market_leverage at time $\mathrm{t}-1$.

Note 2. Cash flow rights held by an external shareholder in firm $i$ are as follows:

$$
Y_{i}=\sum_{j} a_{j, i} Y_{j}+X_{i}
$$

where $a_{j, i}$ is the direct stake held by firm $j$ in firm $i$; $Y_{j}$ and $Y_{i}$ are cash flow rights held by an external shareholder, respectively, in firm $j$ and in firm $i ; X_{i}$ is the direct stake held by the same external shareholder in firm $i$. We have to estimate $Y_{i}$ by solving a system of linear equations; the number of equations and unknowns corresponds to the number of firms in the group.

Note 3. When the majority stake is held by an individual owner, we also require at least a relative of the controlling shareholder on the board. This condition allows us to exclude cases in which the firm is controlled by professional managers without any family involvement.

Note 4. The half-life can be calculated as follows: $\ln (1 / 2) / \ln (\lambda)$. 


\section{Copyrights}

Copyright for this article is retained by the author(s), with first publication rights granted to the journal.

This is an open-access article distributed under the terms and conditions of the Creative Commons Attribution license (http://creativecommons.org/licenses/by/3.0/). 